\title{
Populasi
}

\section{Dinamika Komposisi Penduduk: Dampak Potensial Pandemi Covid-19 terhadap Demografi di Indonesia}

\author{
Sari Lestari Zainal Ridho dan Syaiful Aqli Yusuf \\ Politeknik Negeri Sriwijaya, Palembang, Sumatera Selatan \\ Korespondensi: Sari Lestari Zainal Ridho (e-mail: sarilestari@polsri.ac.id)
}

\begin{abstract}
Abstrak
Penelitian ini bertujuan untuk mengobservasi dan menganalisis tren perkembangan Covid-19 dan potensi dampaknya terhadap perubahan komposisi penduduk berdasarkan struktur usia di Indonesia. Penelitian ini dilatarbelakangi terjadinya pandemi Covid-19 yang berdampak, baik langsung maupun tidak langsung, terhadap kehidupan penduduk atau sumber daya manusia. Dampak tersebut muncul karena adanya peristiwa sakit dan mati yang menjadi fakta yang bertolak belakang dari prediksi kondisi peningkatan usia harapan hidup yang seharusnya dialami oleh masyarakat Indonesia. Dengan menggunakan data kasus Covid-19 dan teknik proyeksi dengan membandingkan beberapa model, temuan penelitian ini menunjukkan bahwa terdapat tren peningkatan kasus selama belum ada intervensi, yaitu jumlah kematian riil didominasi oleh penduduk laki-laki dan penduduk usia lanjut yang berpotensi menyebabkan perubahan komposisi penduduk. Intervensi kebijakan di sektor kesehatan yang lebih tepat guna perlu segera dilakukan untuk menjaga keberlanjutan sumber daya manusia Indonesia karena perubahan demografi, khususnya jenis kelamin, struktur usia, dan kondisi kesehatan penduduk memiliki implikasi makroekonomi yang signifikan.
\end{abstract}

Kata kunci: covid-19; demografi; mortalitas; sumber daya manusia 


\title{
Population Composition Dynamics: A Potential Impact of Covid-19 Pandemic on Demography in Indonesia
}

\begin{abstract}
This study aims to observe and analyze the development of trend of COVID 19 and its potential impact on changes in population composition based on age structure in Indonesia. Using Covid-19 cases data obtained from the Ministry of Health of the Republic of Indonesia and forecasting method by comparing several models, the study findings indicate that the trend shows increasing cases and will continue to rise as long as there is no intervention. Experimentally, the mortality cases dominated by the male and elderly population are the possible causes to the change in the composition of the population based on the age structure. Hence, it is necessary to immediately intervene it in the form of policies in health sector that are more appropriate to maintain the sustainability of Indonesia's human resources since demographic dynamics, particularly in terms of sex, age structure, and health conditions, also have a significant macroeconomic implication.
\end{abstract}

Keywords: covid-19; demography; mortality; human resources

\section{Pendahuluan}

Kemunculan virus corona di tahun 2019 (atau disebut sebagai Covid-19) hingga saat ini menjadi sebuah pandemi yang memiliki dampak langsung dan tidak langsung di berbagai sektor, baik publik, maupun nonpublik, serta berbagai bidang kehidupan, termasuk kependudukan. Sebelum terjadi pandemi, proyeksi kependudukan menunjukkan adanya peningkatan usia harapan hidup dari penduduk Indonesia yang disertai meningkatnya jumlah penduduk usia muda.

Meski demikian, pandemi mengakibatkan sejumlah penduduk sakit dan mati, serta adanya dominasi penduduk usia lanjut yang mengalami kematian, sehingga penting untuk melakukan proyeksi terhadap jumlah tingkat sakit dan tingkat kematian yang mungkin terjadi serta menganalisis potensi pengaruhnya terhadap pembentukan kembali komposisi struktur usia penduduk. Hal ini seperti sebuah fakta yang bertolak belakang dengan dalil dari Demographic Transition Theory yang menyatakan bahwa akan ada banyak penduduk berusia produktif dan terjadi periode aging population yang terjadi akibat peristiwa transisi demografi yang menimbulkan perubahan struktur usia dan selanjutnya mengakibatkan peningkatan usia harapan hidup yang berdampak pada jangka waktu bekerja yang lebih lama (Bloom \& Williamson, 1998) sebagai bagian dari dinamisasi struktur usia.

Sebelumnya Indonesia dipercaya menuju struktur penduduk tua (aging population). Hal ini didukung oleh data adanya peningkatan usia harapan hidup penduduk Indonesia dari 69,8 tahun pada 2010 menjadi 70,9 tahun pada 2017. 
Berdasarkan data dari sumber yang sama (KEMENKES, 2020), proyeksi penduduk lanjut usia selama periode tahun 2010-2035 menunjukan adanya peningkatan jumlah penduduk lanjut usia dari 18 juta jiwa $(7,56 \%)$ pada 2010 menjadi 25,9 juta jiwa $(9,7 \%)$ dan menjadi 27,1 juta jiwa (9,99\%) pada 2020. Kemudian jumlah ini diproyeksi menjadi 42,0 juta jiwa $(13,82 \%)$ pada 2030 dan meningkat menjadi 48,2 juta jiwa $(15,77 \%)$ pada 2035 . Hal ini penting untuk ditelaah tentang bagaimana perkembangan atau tren dari kasus terinfeksi, kasus kematian, dan kasus sembuh, mengingat hal ini terkait dengan sumber daya manusia yang merupakan aset penting dan berpengaruh dalam pengelolaan negara.

Berdasarkan alasan adanya kebutuhan untuk mengetahui secara tepat perubahan komposisi penduduk akibat pandemi COVID 19, penelitian ini bertujuan untuk mengamati tren dari kasus terinfeksi, kematian, dan sembuh secara tepat dengan melakukan prediksi kecenderungan dari data yang ada dengan menggunakan beberapa metode. Menggunakan bantuan model yang sesuai dan penggunaan data yang tersedia, beberapa perkiraan yang dapat diandalkan terhadap kasus yang terinfeksi, kasus aktif, pemulihan, dan kematian dapat dibuat untuk masa depan. Data-data ini berguna untuk memberikan perkiraan tentang jumlah kasus konfirmasi atau positif (infected cases/ morbidity) yang mencerminkan wabah pandemi COVID-2019 serta kematian dan pemulihan dalam perawatan. Dengan demikian, data tersebut mewakili alat yang valid dan obyektif. Berbeda dengan penelitian-penelitan sebelumnya (Aslam, 2020; Khan\& Gupta, 2020; Kırbaşetal., 2020), penelitian ini tidak hanya mengestimasi atau memproyeksi tren yang akan terjadi, atau memantau prevalensi dan kontrol infeksi, tetapi juga menganalisis potensi dampak terhadap sumber daya manusia, khususnya dari perspektif kependudukan.

Pandemi yang ditimbulkan oleh penyakit berpotensi memiliki dampak terhadap sumber daya manusia, baik langsung maupun tidak langsung. Secara langsung, pandemi berpotensi mengakibatkan terjadinya morbiditas dan mortalitas dan secara tidak langsung berpengaruh terhadap sektor kesehatan (The World Bank, 2014), serta berpotensi menimbulkan dampak berkelanjutan terhadap perpanjangan usia yang seharusnya dicapai (Karagiannis \& Karagiannis, 2020; McGillivray, 1991).

Morbiditas dan mortalitas yang dialami sebagai akibat terjadinya pandemi Covid-19 berpengaruh terhadap eksistensi sumber daya manusia dalam lingkup dinamika kependudukan. Dinamisasi populasi dapat berupa perubahan dalam hal stuktur usia dengan bentuk dan dampak yang beragam (Bender, 2018). Salah satu dampak dari sakit dan kematian yang terjadi akibat pandemi adalah pengurangan jumlah penduduk yang berpotensi memengaruhi komposisi penduduk, karena komposisi penduduk merupakan susunan demografis dari populasi yang ada dalam suatu wilayah geografis (Pol \& Thomas, 2002). Susunan demografis populasi tersebut dapat digambarkan berdasarkan karakteristik usia atau jenis kelamin.

Berdasarkan data yang ada di Indonesia, penduduk lanjut usia merupakan kelompok usia dengan angka kematian tertinggi akibat Covid-19, yaitu sekitar sebesar 44\%. Lanjut usia, sesuai dengan Undang-Undang dan Badan Kesehatan Dunia, adalah seseorang dengan usia 60 tahun ke atas (Sumber: Situs Resmi Penanggulangan Covid-19 Pemerintah Indonesia, 2020, covid.go.id). 


\section{Metode Penelitian}

Data yang digunakan dalam penelitian ini adalah data sekunder, yaitu data kasus terinfeksi (kasus positif atau kasus morbiditas), data kasus kematian, kasus sembuh, dan kasus pasien dalam perawatan akibat Covid-19 yang bersumber dari institusi yang kompeten, yaitu Kementerian Kesehatan Republik Indonesia dan Badan Pusat Statistik Indonesia

Pada penelitian ini,teknik proyeksi terhadap perkembangan mortalitas dan morbiditas akibat pandemi COVID 19 dilakukan dengan menggunakan model-model prediksi yang diharapkan dapat memberikan hasil prediksi yang lebih baik dan dipercaya bahwa modelmodel yang lebih kompleks tidak berarti selalu memberikan hasil yang lebih dari modelmodel yang lebih sederhana, seperti modelmodel prediksi klasik (Hibon \& Makridakis, 2000). Prediksi data statistik yang bersifat runtun waktu pada sampel kecil biasanya menggunakan model prediksi klasik, seperti moving average dan exponential smoothing model dalam menghasilkan beberapa data prediksi yang akan datang (Moving Average Model/MA model).

Penelitian ini menggunakan model MA(1) dan MA(2), yaitu model MA(1) juga mewakili Naïve model. Exponential smoothing model dimodelkan untuk data series yang stasioner sebagai Single Exponential Smoothing Model (SES model) dan untuk data series dengan trend dikembangkan menggunakan Holt's method, yaitu Double Exponential Smoothing Model (DES model) (Hanke, John E.;Wichern, 2014).

Untuk mendapatkan proyeksi yang lebih baik, sebagai tambahan pembanding, penelitian ini menggunakan salah satu model prediksi modern, yaitu autoregressive integrated-moving average model atau ARIMA Box-Jenkins model. Kelima model tersebut digunakan dalam perbandingan untuk mendapatkan model prediksi Covid-19 untuk data kasus terinfeksi atau positif, kasus kematian, sembuh, dan pasien dalam perawatan (PDP). Penerapan model prediksi dilakukan dengan bantuan perangkat lunak Minitab 16. Lebih lanjut, untuk perbandingan akurasi, evaluasi kinerja model prediksi juga dilakukan, yaitu nilai mean absolute percentage error (MAPE) dengan rumus sebagai berikut:

$M A P E=\frac{100}{n} \sum_{t=1}^{n}\left|\frac{e_{t}}{Y_{t}}\right|, \quad$ dengan $e_{t}=Y_{t}-\hat{Y}_{t}$

MAPE mengukur persentase kesalahan relatif mutlak dari prediksi yang diberikan model prediksi untuk data pengamatan. Nilai $Y_{t}$ mewakili nilai aktual time series dan $\hat{Y}_{t}$ adalah nilai prediksi (forecast). Nilai kesalahan prediksi disimbolkan dengan $e_{t}$ dan banyaknya data time series disimbolkan dengan $n$ (Hanke, John E.; Wichern, 2014; Hibon \& Makridakis, 2000).

Alasan penggunaan metode tersebut adalah metode tersebut merupakan metode yang sering digunakan dalam prediksi dan memiliki keunggulan, yaitu sederhana dalam pengaplikasiannya dan dapat digunakan pada data nonstasioner dalam melakukan prediksi matematis (Duan \& Zhang, 2020; Singh et al., 2020). Oleh sebab itu, teknik tersebut sering digunakan dalam penelitian yang bertujuan untuk melakukan prediksi.

\section{Hasil dan Pembahasan}

Berdasarkan hasil pengolahan data melalui beberapa model prediksi, peneliti memeroleh ukuran kinerja model berupa nilai MAPEdari hasil perbandingan akurasi model. Nilai inilah yang menentukan apakah model prediksi terpilih sebagai model terbaik atau tidak. 
Sari Lestari Zainal Ridho dan Syaiful Aqli Yusuf

Tabel 1. Hasil Nilai MAPE sebagai Ukuran Perbandingan Model-Model Prediksi

\begin{tabular}{lllllll}
\hline \multirow{2}{*}{ Set } & \multicolumn{5}{c}{ Model } & \multirow{2}{*}{ Best Model } \\
\cline { 2 - 6 } & MA(1) & MA(2) & SES & DES & ARIMA & \\
\hline Kasus Terinfeksi & 4,12432 & 6,13457 & 2,83779 & 1,11286 & $\mathbf{0 , 9 8 8 9 5 7}$ & ARIMA(0,2,1) \\
\hline Kasus Kematian & 3,43744 & 5,07228 & 2,66151 & 1,65504 & $\mathbf{1 , 5 4 3 0 7}$ & ARIMA $(0,2,1)$ \\
\hline Sembuh & 6,57645 & 9,80617 & 5,13119 & $\mathbf{2 , 7 1 5 2 5}$ & $\mathbf{2 , 8 4 8 8 7}$ & DES \\
\hline Dalam Perawatan & 3,68770 & 5,36991 & 2,74136 & 1,37061 & $\mathbf{1 , 1 4 4 9}$ & ARIMA(0,2,1) \\
\hline
\end{tabular}

Sumber: Pengolahan data, 2020

Model ARIMA Box-Jenkins secara umum dirumuskan sebagai model $\operatorname{ARIMA}(p, d, q)$

$$
\Phi_{p}(B)(1-B)^{d}\left(z_{t}-\mu\right)=\Theta_{q}(B) a_{t}
$$

\section{Keterangan:}

$z_{t}=$ nilai pengamatan deret waktu periode ke-t.

$\mu \quad=$ nilai mean pada nilai pengamatan deret waktu.

$B=$ operator Backshift (mundur) pada periode ke-t.

$a_{t}=$ residual atau komponen noise pada periodeke-t.

$\Phi_{p}(B)=\left(1-\phi_{1} B-\phi_{2} B^{2}-\cdots-\phi_{p} B^{p}\right)$.

$\Theta_{q}(B)=\left(1-\theta_{1} B-\theta_{2} B^{2}-\cdots-\theta_{q} B^{q}\right)$.

$d=$ orde proses differencing atau integrated.

Model $\operatorname{ARIMA}(p, d, q)$ dengan orde $p=0, d$ $=2$, dan $q=1$ disederhanakan dari model umum menjadi:

$\Phi_{p}(B)(1-B)^{d}\left(z_{t}-\mu\right)=\Theta_{q}(B) a_{t}$

$\Phi_{0}(B)(1-B)^{2}\left(z_{t}-\mu\right)=\Theta_{1}(B) a_{t}$

$(1-B)^{2}\left(z_{t}-\mu\right)=\left(1-\theta_{1} B\right) a_{t}$

$\left(1-2 B+B^{2}\right)\left(z_{t}-\mu\right)=\left(1-\theta_{1} B\right) a_{t}$

$\left(z_{t}-2 B z_{t}+B^{2} z_{t}\right)-\left(\mu-2 B \mu+B^{2} \mu\right)=a_{t}-\theta_{1} B a_{t}$

$\left(z_{t}-2 z_{t-1}+z_{t-2}\right)-C=a_{t}-\theta_{1} a_{t-1}$

$z_{t}=2 z_{t-1}-z_{t-2}+C-\theta_{1} a_{t-1}+a_{t}$
Model $\operatorname{ARIMA}(0,2,1)$ diperoleh dengan rumusan:

$z_{t}=2 z_{t-1}-z_{t-2}+C-\theta_{1} a_{t-1}+a_{t}$

Kasus terinfeksi dimodelkan dengan model $\operatorname{ARIMA}(0,2,1)$ menjadi:

$z_{t}=2 z_{t-1}-z_{t-2}+11.305-0.9095 a_{t-1}+a_{t}$

Kasus kematian dimodelkan dengan model $\operatorname{ARIMA}(0,2,1)$ menjadi:

$z_{t}=2 z_{t-1}-z_{t-2}+0.3333-0.9820 a_{t-1}+a_{t}$

Kasus dalam perawatan dimodelkan dengan model $\operatorname{ARIMA}(0,2,1)$ menjadi:

$z_{t}=2 z_{t-1}-z_{t-2}+3.063-0.9747 a_{t-1}+a_{t}$

Model Double Exponential Smoothing (DES) atau Holt's model secara umum dirumuskan:

1. Deret Exponential Smoothed

$L_{t}=\alpha Y_{t}+(1-\alpha)\left(L_{t-1}+T_{t-1}\right)$

2. Estimasi Trend

$T_{t}=\gamma\left(L_{t}-L_{t-1}\right)+(1-\gamma) T_{t-1}$

3. Meramalkan $m$ periode ke depan

$\hat{Y}_{t+m}=L_{t}+m T_{t}$ 
Kasus sembuh dimodelkan dengan model DES menjadi:

$L_{t}=0.636120 Y_{t}+(1-0.636120)\left(L_{t-1}+T_{t-1}\right)$

$T_{t}=0.567384\left(L_{t}-L_{t-1}\right)+(1-0.567384) T_{t-1}$

$\hat{Y}_{t+m}=L_{t}+m T_{t}$

Hasil terbaik pada series Recoveries jatuh pada model DES atau Double Exponential Smoothing Model atau Holt's method dengan nilai MAPE sebesar $2.71525 \%$, artinya persentase kesalahan relatif mutlak dari prediksi yang diberikan model DES untuk series recoveries sebesar $2.71525 \%$. Berdasarkan hasil set yang lain, model ARIMA orde [p
$=0, d=2, q=1]$ atau $\operatorname{ARIMA}(0,2,1)$ menjadi model terbaik pada infected cases (kasus terinfeksi), mortality cases (kasus kematian), dan -n-care patient (kasus pasien dalam perawatan) dengan nilai MAPE masing-masing sebesar $0.988957 \%, 1.54307 \%$, dan $1.14494 \%$. Dari orde integrated atau $d$ sebesar 2, pola tren yang naik memiliki derajat dua kali dari tren naik biasa, sehingga hal ini menunjukkan bahwa peningkatan set pada infected cases, mortality cases, dan in-care patient yang sangat pesat. Hal ini diilustrasikan data time series plot sebagai berikut:

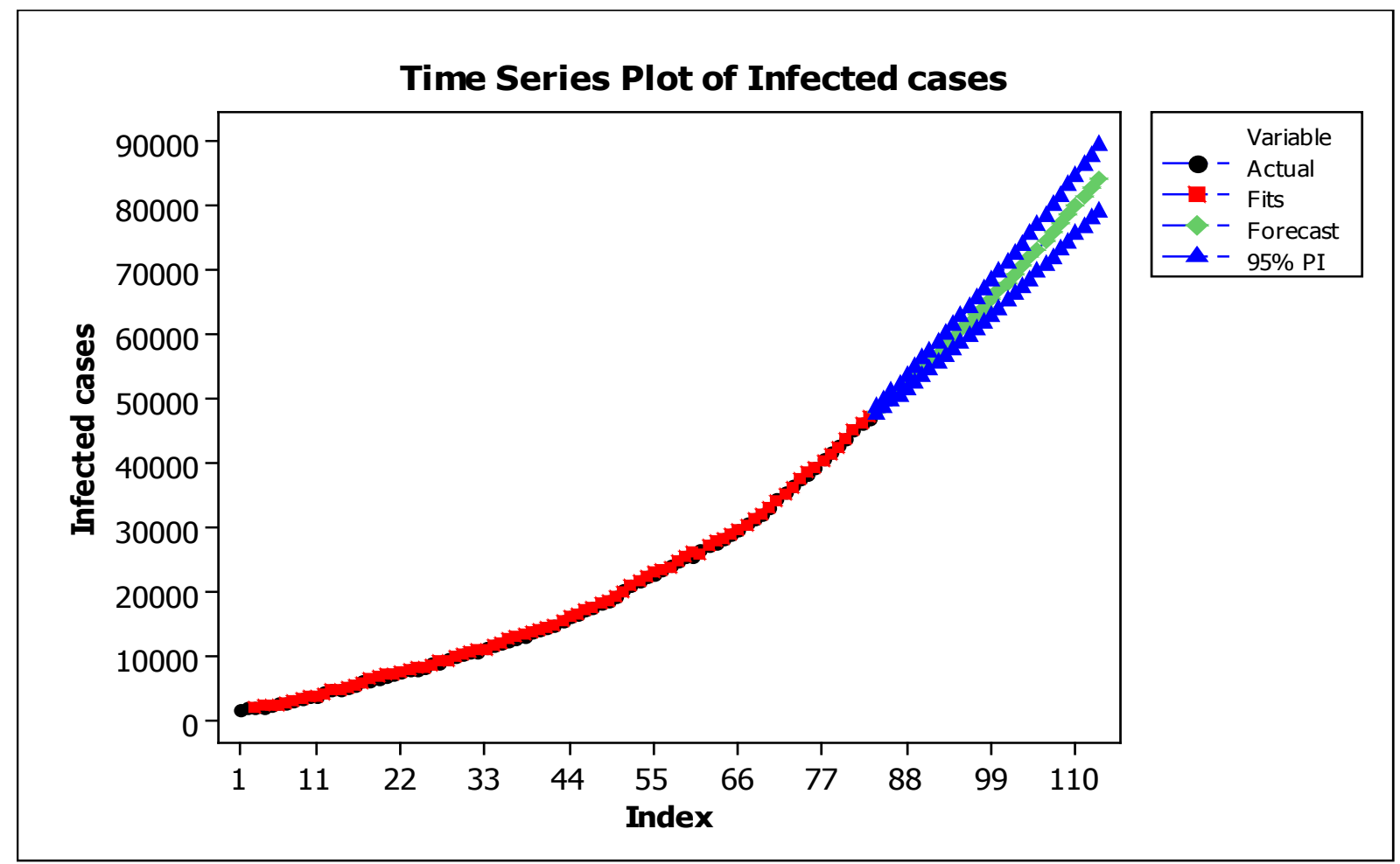

Sumber: Data yang diolah, 2020

Gambar 1. Plot Data Time Series Kasus Terinfeksi 


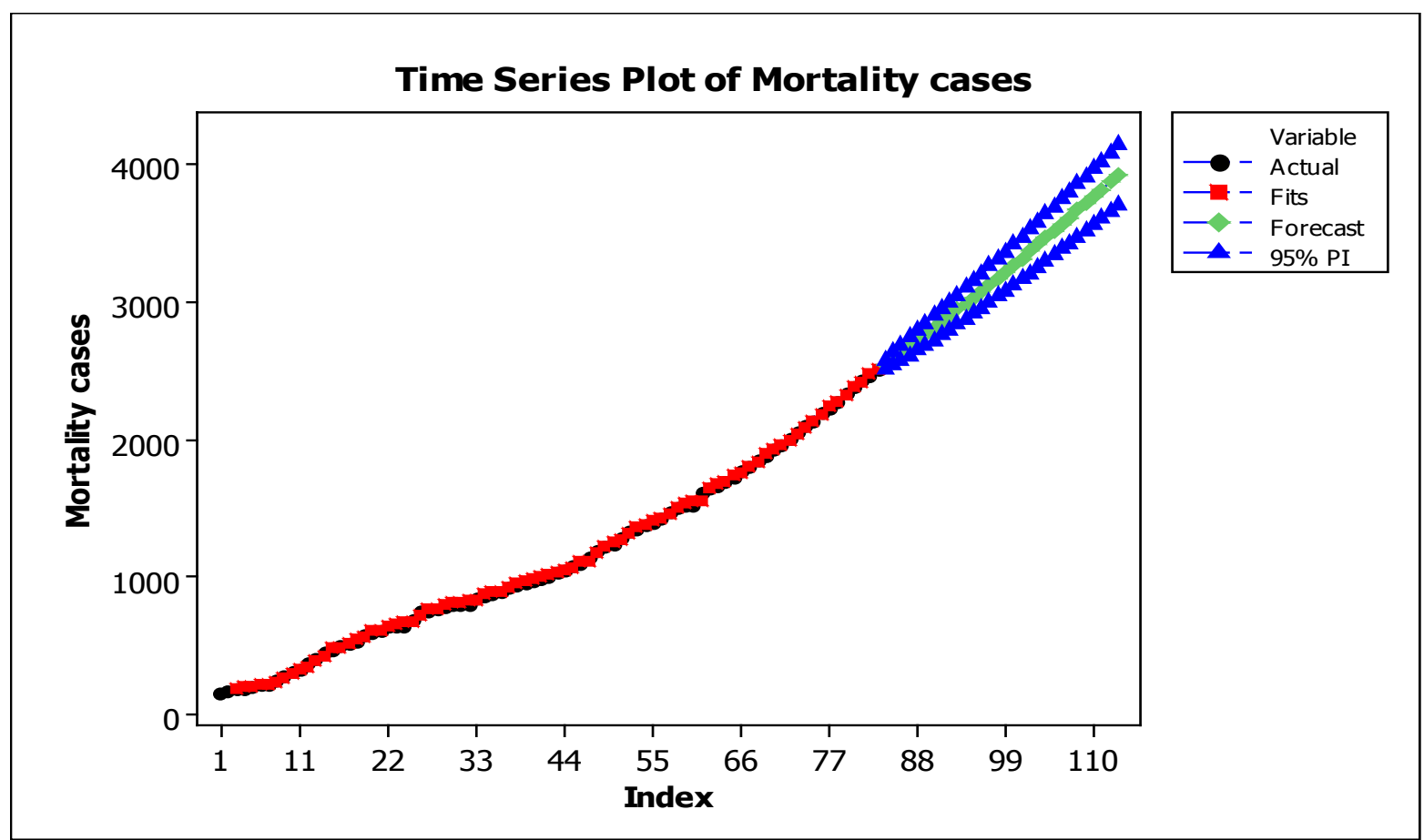

Sumber: Data yang diolah, 2020

Gambar 2. Plot Data Time Series Kasus Kematian

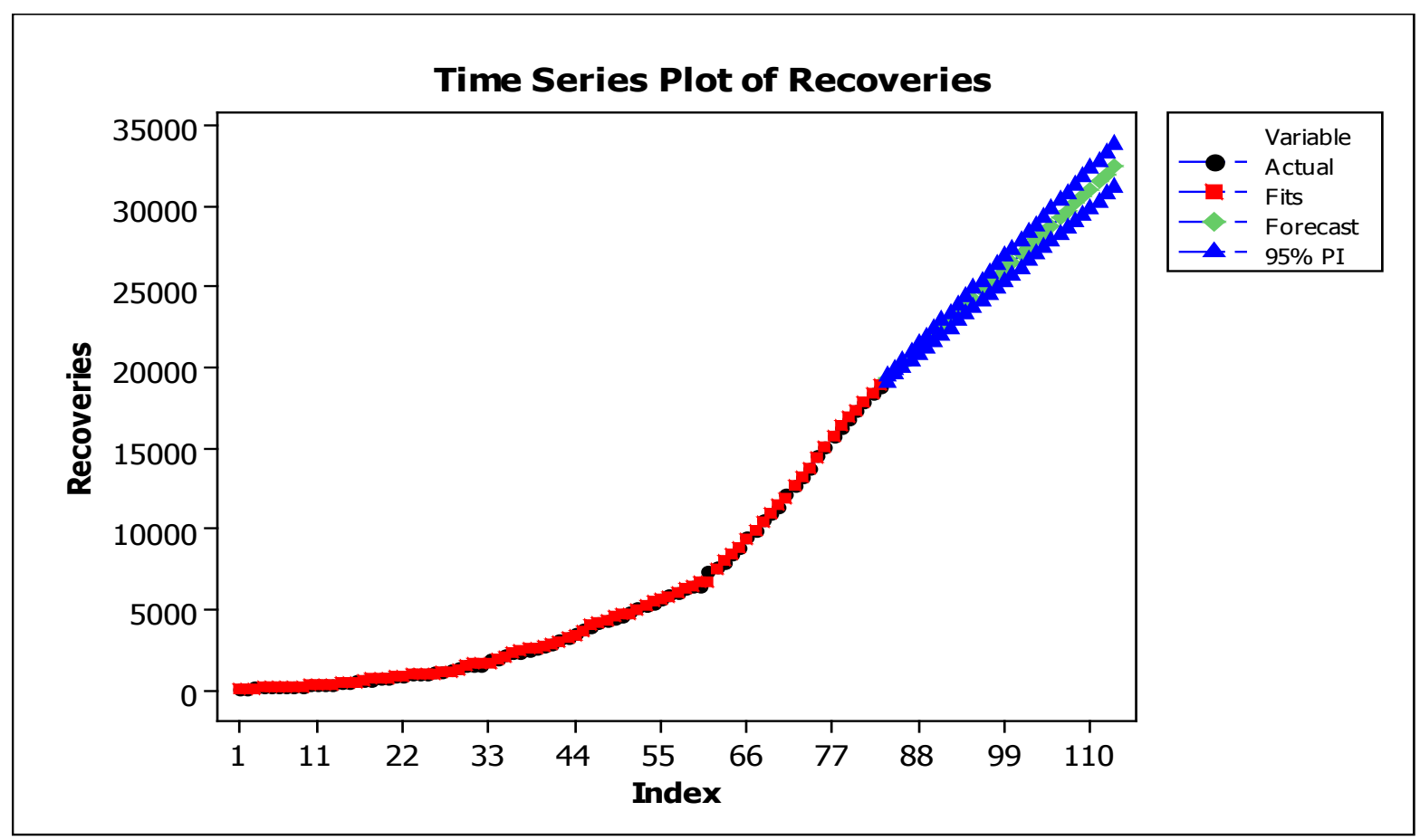

Sumber: Data yang diolah, 2020

Gambar 3. Plot Data Time Series Pasien Sembuh 


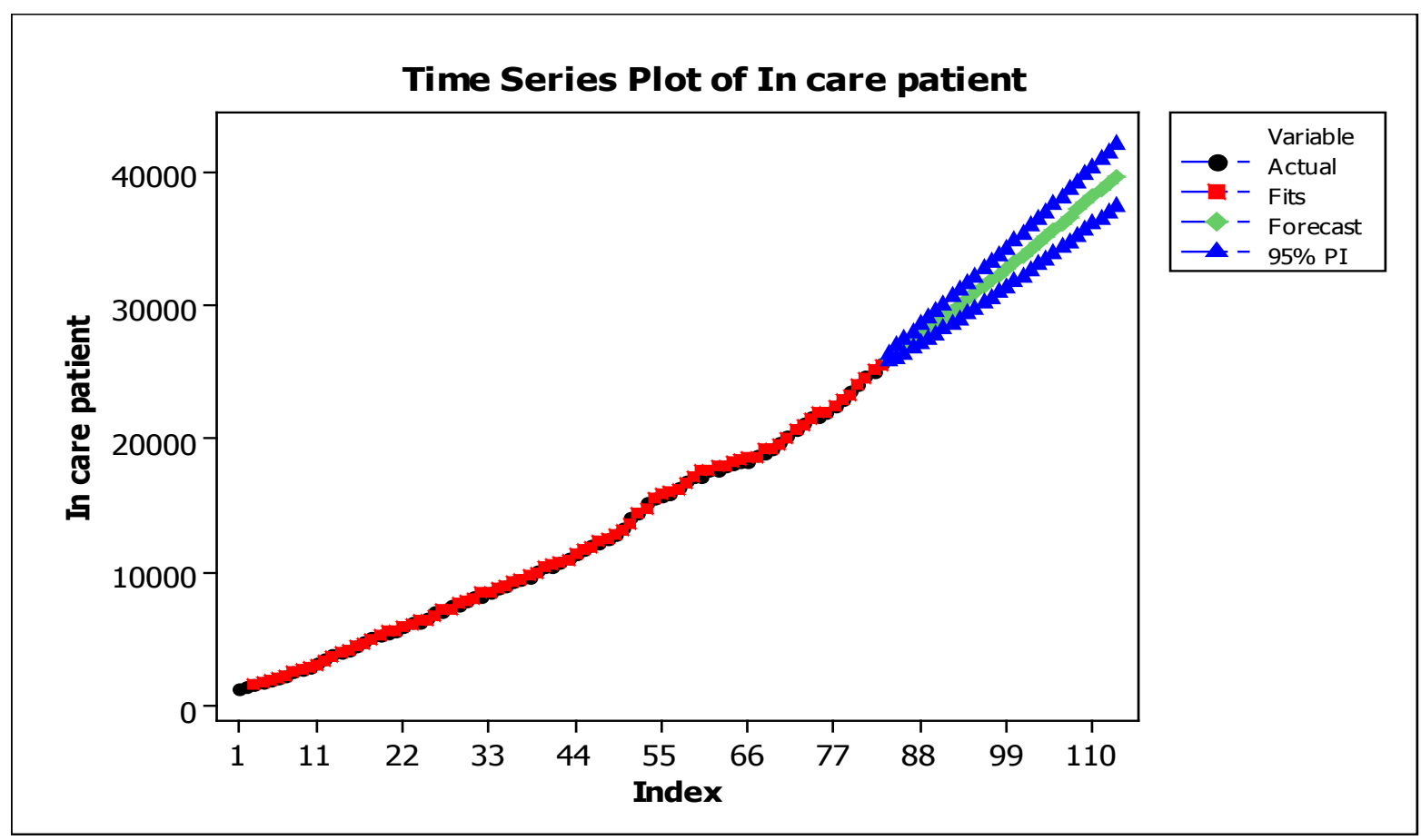

Sumber: Data yang diolah, 2020

\section{Gambar 4. Plot Data Time Series Pasien dalam Perawatan}

Model prediksi terbaik pada masingmasing series menghasilkan prediksi di masa depan pada pola tren naik untuk 30 periode. Pola ini akan terjadi secara masif jika tidak ada intervensi eksternal, seperti pengambilan keputusan pihak berwenang atau dampak lain. Jika data riil di masa depan terjadi atau jatuh diluar interval prediksi 95\%, maka model akan direvisi dengan penambahan data baru dan dilakukan perbandingan model kembali. Model prediksi yang terbentuk memiliki akurasi yang baik, meskipun model tidak kompleks. Berikut hasil prediksi yang perlu menjadi pertimbangan pihat terkait. 
Sari Lestari Zainal Ridho dan Syaiful Aqli Yusuf

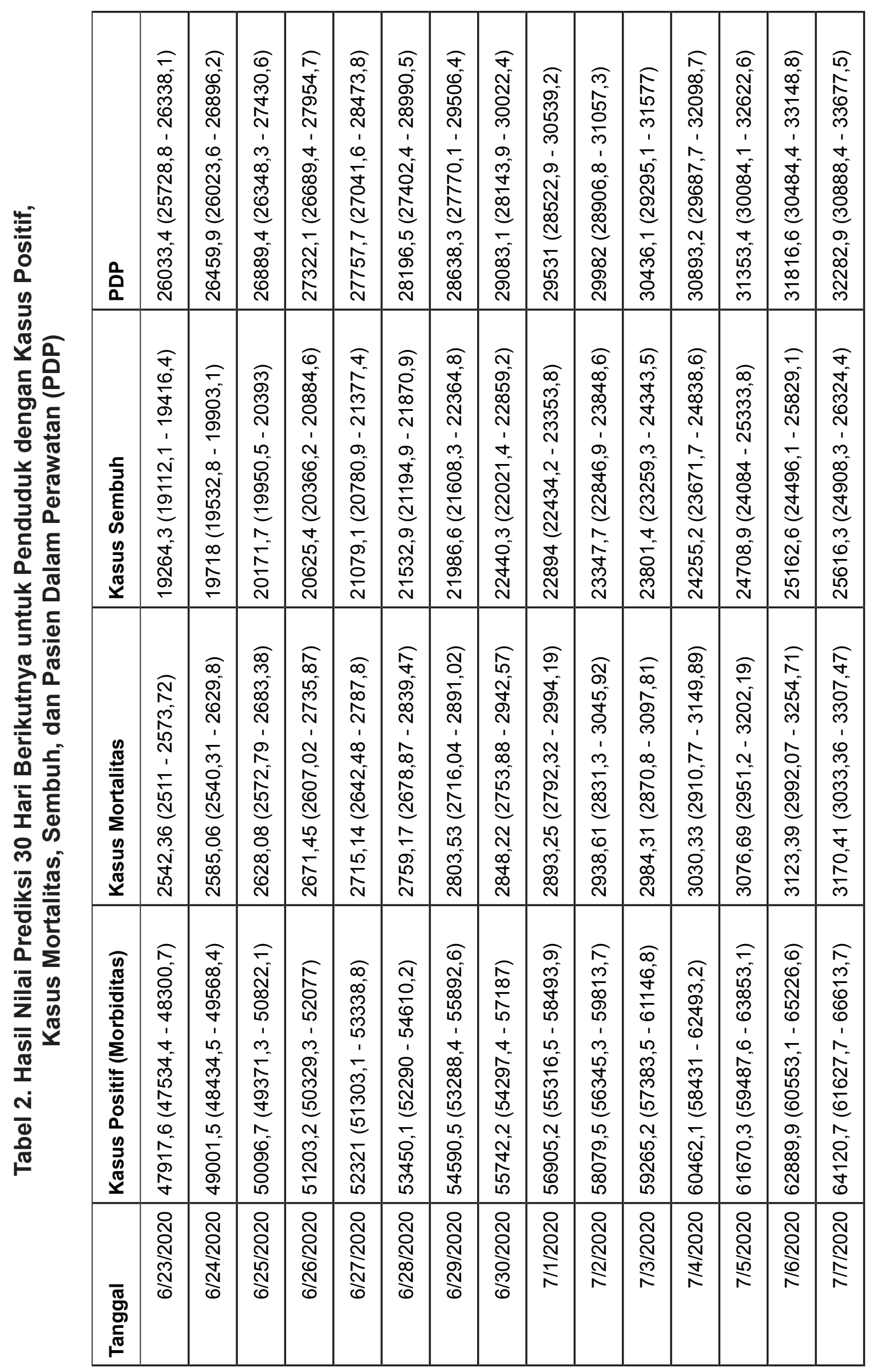




\begin{tabular}{|c|c|c|c|c|c|c|c|c|c|c|c|c|c|c|c|}
\hline $\begin{array}{l}0 \\
\text { 口 }\end{array}$ & 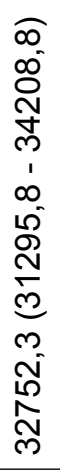 & 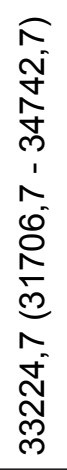 & 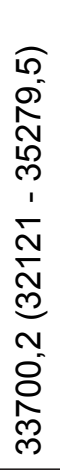 & 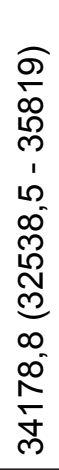 & 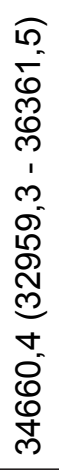 & 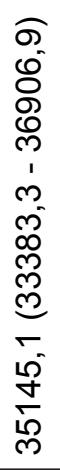 & 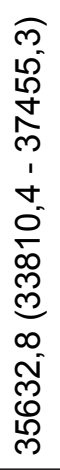 & 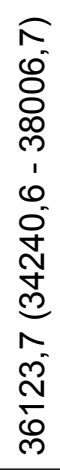 & 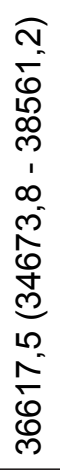 & 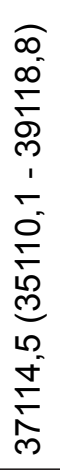 & 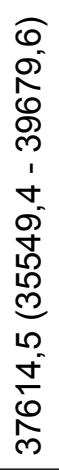 & 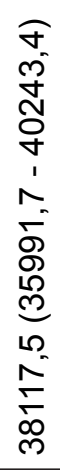 & 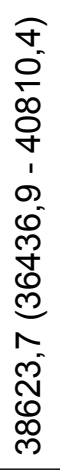 & 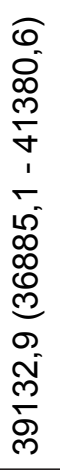 & 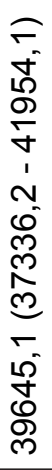 \\
\hline 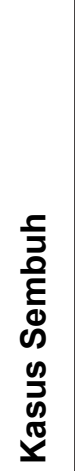 & 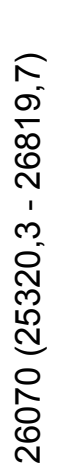 & 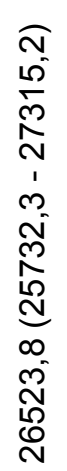 & 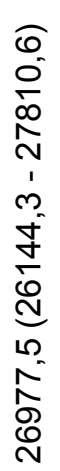 & 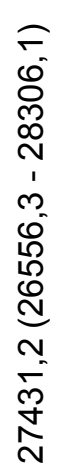 & 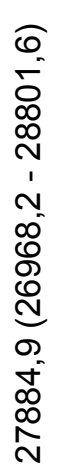 & 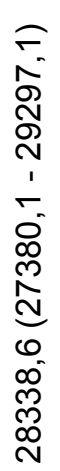 & 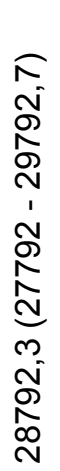 & 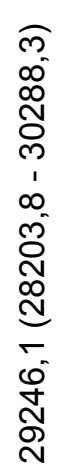 & 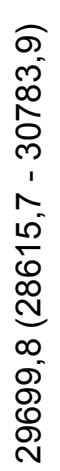 & 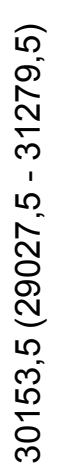 & 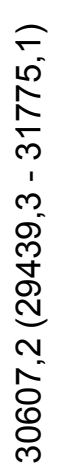 & 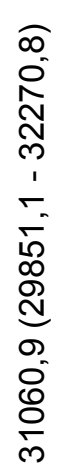 & 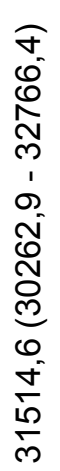 & 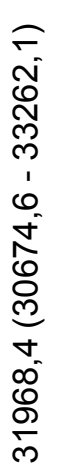 & 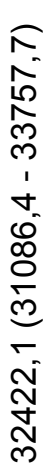 \\
\hline 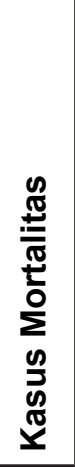 & 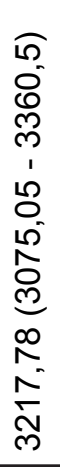 & 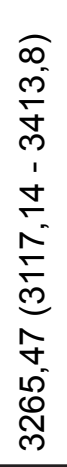 & 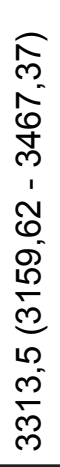 & 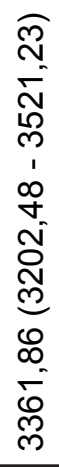 & 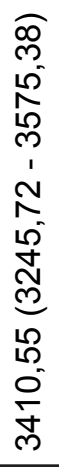 & 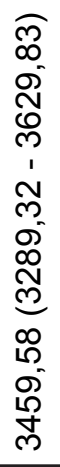 & 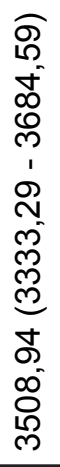 & 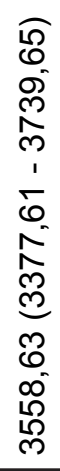 & 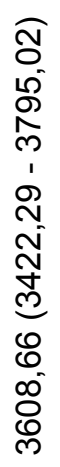 & 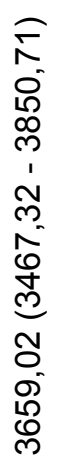 & 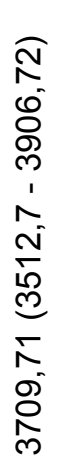 & 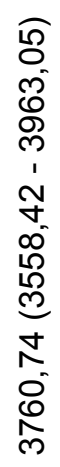 & 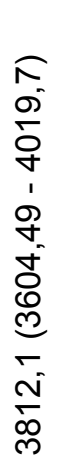 & 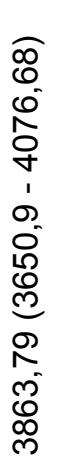 & 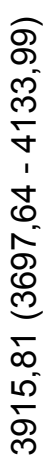 \\
\hline 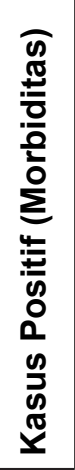 & 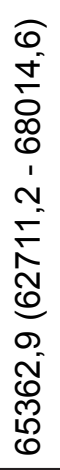 & 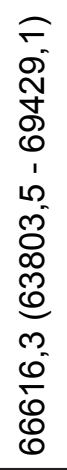 & 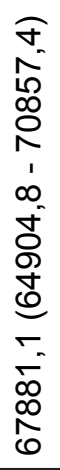 & 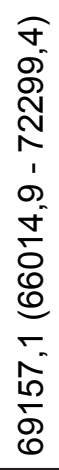 & 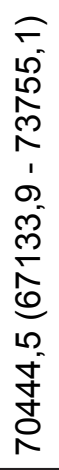 & 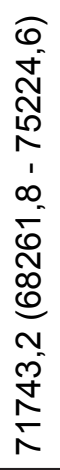 & 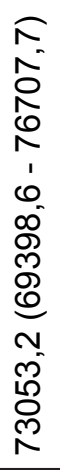 & 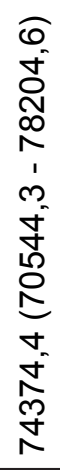 & 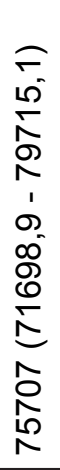 & 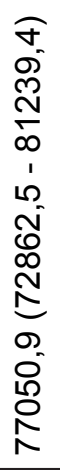 & 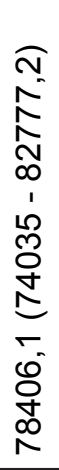 & 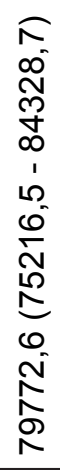 & 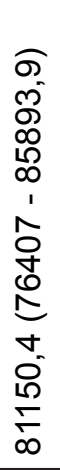 & 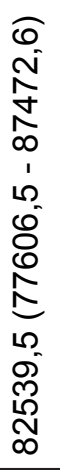 & 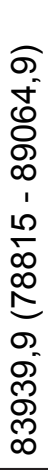 \\
\hline $\begin{array}{l}\overline{\mathbb{\pi}} \\
\stackrel{\circ}{\sigma} \\
\overline{\mathbb{\pi}}\end{array}$ & 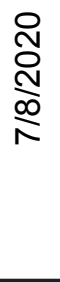 & 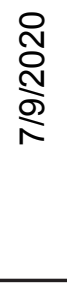 & 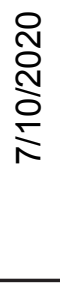 & $\begin{array}{l}\stackrel{ }{N} \\
\stackrel{N}{\Sigma} \\
\frac{N}{\Sigma}\end{array}$ & 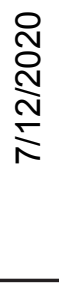 & 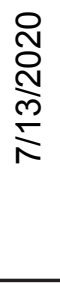 & 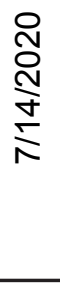 & 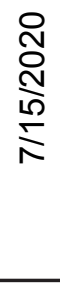 & 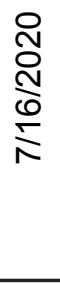 & $\frac{\stackrel{\overbrace{}}{N}}{\stackrel{N}{N}}$ & 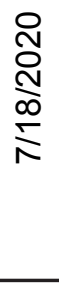 & $\begin{array}{l}\text { ণ } \\
\stackrel{N}{N} \\
\frac{D}{N}\end{array}$ & 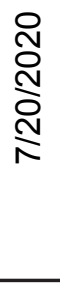 & $\begin{array}{l}\underset{N}{\stackrel{N}{N}} \\
\underset{N}{N}\end{array}$ & $\begin{array}{l}\stackrel{ }{N} \\
\stackrel{N}{N} \\
\underset{N}{N}\end{array}$ \\
\hline
\end{tabular}


Prediksi dilakukan untuk 30 hari berikutnya (23 Juni 2020 hingga 22 Juli 2020) dari data series. Hasil pengolahan data yang tertera pada Tabel 1 dan Tabel 2 menunjukkan bahwa akan terus terjadi peningkatan pada kasus terinfeksi, kasus mortalitas, dan PDP. Meskipun banyak pasien yang sembuh, PDP mengalami peningkatan, yaitu pasien yang sembuh lebih besar dari kasus kematian, namun kasus kematian dan kasus terinfeksi mengalami peningkatan. Hasil pengolahan data tersebut menunjukkan bahwa prediksi jumlah penderita Covid-19 yang mengalami kematian di Indonesia adalah sekitar 3200 kasus perhari untuk 30 hari berikutnya dengan peningkatan sebesar sekitar ratarata 47 kasus perhari, sedangkan prediksi jumlah kasus terinfeksi Covid-19 di Indonesia pada kasus morbiditas adalah sekitar 6500 kasus perhari dengan peningkatan sekitar 1200 kasus perhari.
Temuan ini penting untuk menjadi pertimbangan semua pihak terdampak. Bagi pemerintah, mengeluarkan kebijakankebijakan yang mendukung upaya pencegahan penyebaran Covid-19 perlu untuk dilakukan. Selain itu, penting untuk tidak mengabaikan biaya publik karena implikasi dari pengabaian biaya kebijakan publik dapat berakibat dalam jangka pendek maupun panjang (Persson \& Tinghög, 2020), sebagaimana disebutkan sebelumnya dalam jangka pendek, morbiditas dan mortalitas merupakan dampak dari pandemi, namun dampak tersebut dapat meluas dalam jangka panjang berupa disrupsi diberbagai sektor, termasuk sektor kesehatan. Lebih jauh lagi, hal ini juga berdampak pada kualitas modal manusia, termasuk pendidikan dan kesejahteraan (The World Bank, 2014).

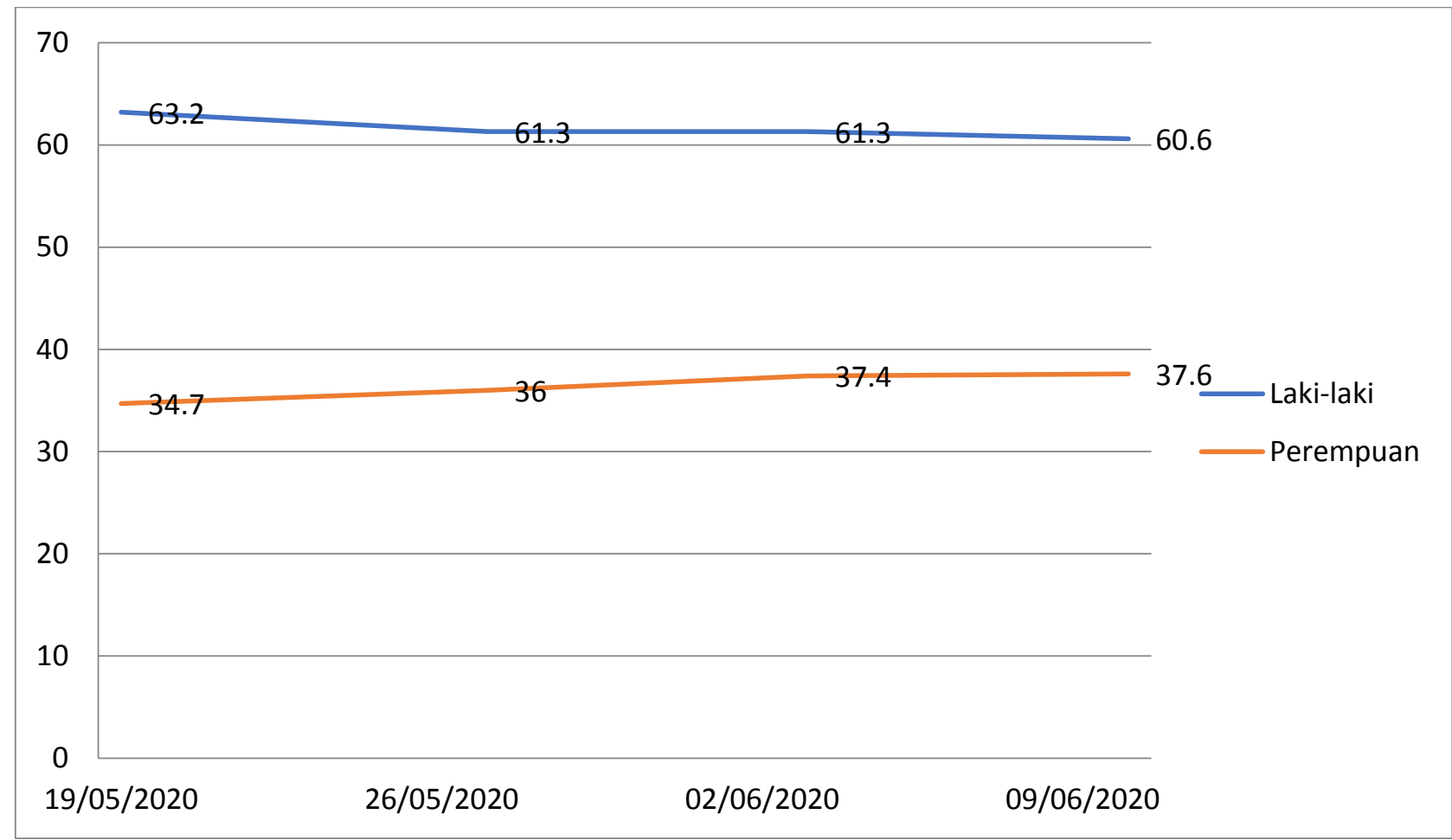

Sumber: Kementerian Kesehatan Republik Indonesia, 2020

(Kementerian Kesehatan Republik Indonesia, 2020b, 2020c, 2020a; Kementerian Kesehatan Republik Indonesia, 2020)

Gambar 5. Kasus Kematian berdasarkan Jenis Kelamin (\%) 
Gambar 5 menunjukkan bahwa, berdasarkan jenis kelamin, tingkat kematian penderita Covid-19 laki-laki lebih tinggi dari perempuan. Alasan yang memungkinkan kondisi ini terjadi adalah, berdasarkan survei yang dilakukan Badan Pusat Statistik
Indonesia, perempuan lebih mengetahui dan menerapkan physical distancing dibandingkan laki-laki, dan perempuan lebih disiplin dalam menjaga kebersihan dengan sering mencuci tangan menggunakan sabun (Putranto, etal., 2020).

Tabel 3. Kasus Kematian berdasarkan Jenis Kelamin (\%)

\begin{tabular}{lrrrr}
\hline Jenis Kelamin & \multicolumn{4}{c}{ Tanggal } \\
\cline { 2 - 5 } & $\mathbf{1 9 / 0 5 / 2 0 2 0}$ & $\mathbf{2 7 / 0 5 / 2 0 2 0}$ & $\mathbf{0 3 / 0 6 / 2 0 2 0}$ & $\mathbf{1 0 / 0 6 / 2 0 2 0}$ \\
\hline Laki-laki & 63,2 & 61,3 & 61,3 & 60,6 \\
\hline Perempuan & 34,7 & 36 & 37,4 & 37,6 \\
\hline
\end{tabular}

Sumber: Kementerian Kesehatan Republik Indonesia, 2020

(Kementerian Kesehatan Republik Indonesia, 2020b, 2020c, 2020a; Kementerian Kesehatan Republik Indonesia, 2020)

Tabel 3 menunjukkan besarnya persentase jumlah kasus kematian berdasarkan jenis kelamin. Jumlah kasus kematian banyak terjadi pada penduduk laki-laki dengan persentase jumlah kasus hampir dua kali lipat dari kasus kematian pada penduduk perempuan. Ada lebih banyak laki laki yang mengalami kasus kematian yang berpotensi mengubah komposisi penduduk berdasarkan jenis kelamin.

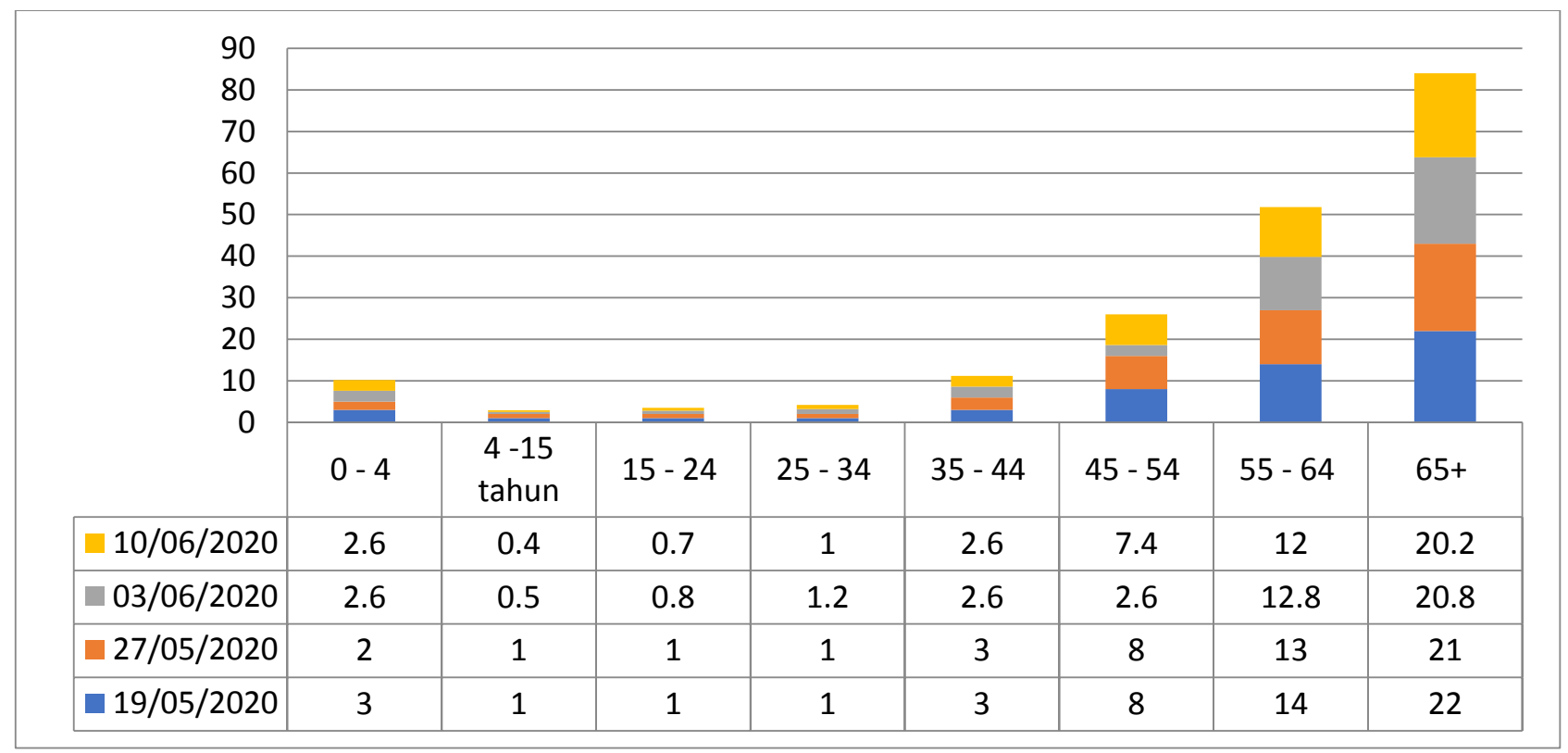

Sumber: Kementerian Kesehatan Republik Indonesia, 2020

(Kementerian Kesehatan Republik Indonesia, 2020b, 2020c, 2020a; Kementerian Kesehatan Republik Indonesia, 2020)

Gambar 6. Kasus Kematian berdasarkan Struktur Umur (\%) 
Laki-laki tidak hanya berpotensi mengubah komposisi penduduk berdasarkan jenis kelamin, tetapi juga berpotensi menciptakan kemiskinan (The World Bank, 2014) karena selama ini di Indonesia, yang menjadi kepala keluarga secara umum adalah laki laki, bukan perempuan. Kematian kepala keluarga mengakibatkan hilangnya pendapatan yang dapat memicu kemiskinan. Selain terciptanya kemiskinan, berdasarkan penelitan terdahulu, perubahan struktur keluarga berupa terjadinya keluarga dengan kepala rumah tangga tunggal (widowhood) berkaitan dengan kondisi kesehatan yang lebih buruk (Lieber et al., 2020).

Lebih lanjut, berdasarkan struktur usia sebagaimana disajikan pada Gambar 6, penduduk usia lanjut mengalami tingkat kematian paling tinggi dibandingkan kelompok usia lainnya (lebih dari 20\%). Berdasakan informasi Kementerian Kesehatan Republik Indonesia, penduduk usia lanjut lebih rentan terdampak Covid-19 dan meningkatkan risiko keparahan penyakit jika ada penyakit penyerta, seperti hipertensi, diabetes mellitus, jantung, dan paru. Dengan demikian, pencegahan Covid-19 pada kelompok lanjut usia harus dilakukan secara optimal karena dapat menyebabkan risiko mengalami gejala yang lebih berat jika terinfeksi Covid-19 (Ika, 2020).

Tingginya jumlah kematian penduduk usia lanjut berpotensi menciptakan perubahan dalam komposisi penduduk dan perubahan distribusi usia dalam populasi memiliki implikasi makroekonomi yang signifikan. Hal ini dibuktikan dari temuan yang menunjukkan pengaruh perubahan distribusi usia dalam populasi terhadap tabungan domestik, penanaman modal dalam negeri, Produk Domestik Bruto (PDB) riil, inflasi, keseimbangan fiskal dan current account balance (Goh et al., 2020).
Temuan hasil penelitian ini juga penting untuk mendapat perhatian karena morbiditas penduduk usia lanjut menjadi constraint pemerolehan dampak positif yang seharusnya diharapkan terjadi dari adanya peristiwa transisi demografi (Bloom \& Williamson, 1998) yang terjadi di Indonesia, yaitu penduduk seharusnya menua dengan sehat, sehingga menjadi produktif dan tidak menjadi beban perekonomian. Namun, morbiditas sebagai dampak pandemi akan menghilangkan semua kesempatan tersebut. Sebagai contoh, terkait dengan anggaran untuk keuangan publik, peningkatan kebutuhan jasa layanan kesehatan bagi penduduk akan menyebabkan peningkatan anggaran dalam hal belanja publik (Peña, 2020).

\section{Kesimpulan dan Rekomendasi}

Penelitian ini bertujuan untuk menganalisis tren perkembangan Covid-19 dan potensi dampaknya terhadap perubahan komposisi penduduk berdasarkan struktur usia. Berdasarkan hasil pengolahan data selama periode1 April 2020 hingga 22 Juni 2020, temuan dari penelitian ini menunjukkan bahwa tren mengalami peningkatan atau akan terus naik untuk kasus terinfeksi, kematian, sembuh, dan PDP. Jumlah penderita Covid-19 yang mengalami kematian di Indonesia untuk 30 hari berikutnya terus berlanjut dari tanggal data yang digunakan untuk mengamati kecenderungan perkembangan pandemi COVID 19 dengan jumlah kasus perhari. Selama belum ada intervensi, dengan kata lain, tren di masa depan akan terus terjadi, yaitu kasus morbiditas dan mortalitas terjadi tanpa adanya intervensi.

Temuan tersebut disertai dengan jumlah kematian riil yang didominasi oleh 
penduduk laki-laki dan penduduk usia lanjut. Jika hal ini terjadi terus menerus tanpa intervensi, terutama dari pemerintah, maka akan berpotensi menimbulkan terjadinya perubahan komposisi penduduk berdasarkan jenis kelamin dan struktur usiayang memiliki implikasi dari potensi dampak tersebut, sehingga intervensi berupa kebijakan di sektor kesehatan yang lebih tepat perlu segera dilakukan untuk menjaga keberlanjutan sumber daya manusia Indonesia. Perubahan demografi, khususnya dalam hal jenis kelamin tertentu, struktur usia, dan kondisi kesehatan penduduk, memiliki implikasi makroekonomi secara umum dan implikasi kependudukan secara khusus, seperti dalam hal perubahan struktur keluarga, kemiskinan, penurunan kesehatan, dan dependency ratio yang menunjukkan presentasi penduduk usia nonproduktif yang harus ditanggung sumber daya manusia atau penduduk usia produktif.

Dengan demikian, penting bagi pemerintah untuk melakukan kebijakan yang mampu mengurangi atau mencegah terjadinya peningkatan morbiditas dan mortalitas dengan mempercepat identifikasi serta kesembuhan penduduk yang terinfeksi melalui skema pemberian bantuan dalam proses uji kasus dan perawatan, serta tindakan pencegahan lainnya, seperti tetap menjalankan kebijakan yang membuat masyarakat menghindari kegiatan berkerumun dan penjadwalan karantina terbatas untuk usia tertentu, sehingga dapat mengurangi sakit dan kasus terinfeksi tidak menjadi kasus kematian. Selain peran penting pemerintah, partisipasi masyarakat juga dibutuhkan. Hal ini juga penting untuk membangun kedisiplinan dengan menerapkan physical distancing dan sering mencuci tangan, karena kebijakan pemerintah dalam menghambat penyebaran
Covid-19 tidak akan berjalan dengan baik jika kedisiplinan tidak terbangun dengan baik dari masyarakat.

Kemudian pengembangan kajian mengenai dampak Covid-19 terhadap kependudukan di Indonesia juga perlu dilakukan untuk mengatasi permasalahanpermasalahan yang terjadi, mengingat penelitian ini masih memiliki keterbatasan, yaitu masih berupa analisis potensi dampak dengan menggunakan teknik prediksi dalam jangka pendek. Dengan demikian, peneliti berharap dapat melakukan penelitian menggunakan data dalam jangka panjang dan menguji pengaruh pandemi terhadap kependudukan di Indonesia.

\section{Daftar Pustaka}

Aslam, M. (2020). Using the kalman filter with Arima for the COVID-19 pandemic dataset of Pakistan. Data in Brief, 31, 105854. https://doi.org/10.1016/j. dib.2020.105854.

Bender, L. C. (2018). Age structure and population dynamics. In Encyclopedia of Ecology (2nd ed., Issue October 2017). Elsevier Inc. https://doi. org/10.1016/B978-0-12-4095489.10925-X.

Bloom, D. E., \& Williamson, J. G. (1998). Demographic transitions and economic miracles in emerging Asia. World Bank Economic Review, 12(3), 419-455. https://doi.org/10.1093/ wber/12.3.419.

Duan, X., \& Zhang, X. (2020). ARIMA modelling and forecasting of irregularly patterned COVID-19 outbreaks using Japanese and South Korean data. Data in Brief, 31, 105779. https://doi. org/10.1016/j.dib.2020.105779. 
Goh, S. K., McNown, R., \& Wong, K. N. (2020). Macroeconomic implications of population aging: Evidence from Japan. Journal of Asian Economics, 68, 101198. https://doi.org/10.1016/j. asieco.2020.101198.

Hanke, John E., Wichern, D. (2014). Business Forecasting. In Pearson Education Limited. Pearson Education Limited. https://doi.org/10.16309/j.cnki. issn.1007-1776.2003.03.004.

Hibon, M., \& Makridakis, S. (2000). The M3Competition: Results, conclusions and implications. International Journal of Forecasting, 16, 451-476.

Ika. (2020). Pakar UGM Paparkan Penyebab Lansia Rentan Terinfeksi Covid. April. https://ugm.ac.id/id/berita/19320pakar-ugm-paparkan-penyebablansia-rentan-terinfeksi-covid.

Karagiannis, R., \& Karagiannis, G. (2020). Constructing composite indicators with Shannon entropy: The case of Human Development Index. SocioEconomic Planning Sciences, 70(January 2018), 100701. https:// doi.org/10.1016/j.seps.2019.03.007.

KEMENKES, R. (2020). BERANDA Indonesia Masuki Periode Aging Population LIHAT VERSI MOBILE. Kemenkes, 1-4. https://www.kemkes. go.id/article/view/19070500004/ indonesia-masuki-periode-agingpopulation.html.

Khan, F. M., \& Gupta, R. (2020). ARIMA and NAR based Prediction Model for Time Series Analysis of COVID-19 cases in India. Journal of Safety Science and Resilience, 1(April), 12-18. https:// doi.org/10.1016/j.jnlssr.2020.06.007.

Kırbaş, İ., Sözen, A., Tuncer, A. D., \& Kazancıoğlu, F. Ş. (2020). Comparative analysis and forecasting of COVID-19 cases in various European countries with ARIMA, NARNN and LSTM approaches.
Chaos, Solitons and Fractals, 138. https://doi.org/10.1016/j.chaos. 2020.110015.

Lieber, J., Clarke, L., Timæus, I. M., Mallinson, P. A. C., \& Kinra, S. (2020). Changing family structures and self-rated health of India's older population (1995-96 to 2014). SSM - Population Health, 11(August 2019), 100572. https://doi. org/10.1016/j.ssmph.2020.100572.

McGillivray, M. (1991). The human development index: Yet another redundant composite development indicator? World Development, 19(10), 1461-1468. https://doi.org/10. 1016/0305-750X(91)90088-Y.

Peña, W. (2020). Population Aging and Public Finances: Evidence from El Salvador. Journal of the Economics of Ageing, 17(April), 100260. https:// doi.org/10.1016/j.jeoa.2020.100260.

Persson, E., \& Tinghög, G. (2020). Opportunity cost neglect in public policy. Journal of Economic Behavior and Organization, 170, 301-312. https://doi.org/10.1016/j.jebo. 2019.12.012.

Putranto, Windhiarso Ponco Adi;Larasaty, Putri;Kurniasih, Anna; Pratiwi, Aprilia Ira; Saputri, Valent Gigih; Meilianingsih, T. (2020). Hasil Survei Sosial Demografi Dampak Covid-19 2020 (S. I. Statistik (ed.)). Badan Pusat Statistik. https://doi.org/10.16309/j. cnki.issn.1007-1776.2003.03.004

Republik Indonesia, Kementerian Kesehatan. (2020a). COVID-19 dalam Angka Kondisi 10 Juni 2020. www.kemkes.go.id.

Republik Indonesia, Kementerian Kesehatan. (2020b). COVID-19 dalam Angka Kondisi 27 Mei 2020. www.kemkes.go.id.

Republik Indonesia, Kementerian Kesehatan. (2020c). COVID-19 
dalam Angka Kondisi 3 Juni 2020. www.kemkes.go.id.

Republik Indonesia, Kementrian Kesehatan. (2020). COVID-19 dalam Angka Kondisi 19 Mei 2020. www.kemkes. go.id.

Singh, S., Parmar, K. S., Makkhan, S. J. S., Kaur, J., Peshoria, S., \& Kumar, J. (2020). Study of ARIMA and least square support vector machine (LSSVM) models for the prediction of SARS-CoV-2 confirmed cases in the most affected countries. Chaos, Solitons and Fractals, 139. https://doi. org/10.1016/j.chaos.2020.110086.

The World Bank. (2014). The Economic Impact of the 2014 Ebola Epidemic: Short and Medium Term Estimates for West Africa. The World Bank. https:// doi.org/10.1596/978-1-4648-0438-0. 